\title{
Discrimination and Prejudice: Witch-Hunting during the Covid-19 Pandemic
}

\section{Devina Neogi}

\author{
Ramaiah Public Policy Center, India
}

\begin{abstract}
Historically, witch-hunting is a form of gender-based violence targeting mostly women and driven by societal prejudices. Metaphorically, during the COVID-19 pandemic witch-hunting has come to connote targeted discrimination and violence driven by social prejudices about the disease. People from different groups, communities, and occupations have been the targets of the latter. Simultaneously, although not as frequently, the same people have been the target of hero-welcoming for their role in fighting the spread and consequences of the disease. These incidents seem to confirm that in times of crisis and great uncertainty, people may behave in contradictory ways. They may look for scapegoats to vent their frustrations, worries, and fears based on their prejudices. They may also make heroes of those that provide calm, care, and courage based on their benevolent prejudices. The two opposing dynamics must be managed to minimize their ill-effects and maximize their good effects. The paper presents an ontological framework to understand the antecedents and consequences of the acts, and to manage them effectively. The study aims to propose a way forward to address the issue with the help of the ontological review of the relevant secondary literature.
\end{abstract}

Keywords: prejudice, discrimination, witch-hunt, COVID-19, pandemic response

\section{Introduction}

COVID-19 has caused an unprecedented global crisis, including millions of lives lost, public health systems in shock, and economic and social disruption, disproportionately affecting the most vulnerable groups like low-income communities of color as well as indigenous, immigrant, refugee populations as well as the frontline workers (Haldane et al., 2021) (United Nation Human Rights, 2020). During the pandemic, the acts of violence have negatively impacted or specifically target under-represented economic, physical, psychological, and social acts, illustrating the persistence of occupation-based, region-based, gender-based, or race-based prejudices (United Nations, 2020). Historically, prejudice also serves to target groups and gave rise to witch-hunting ${ }^{1}$ since the $15^{\text {th }}$ century. It was used to threaten women who were perceived as upsetting the social balance ${ }^{2}$ (Neogi, 2020). However, the term witch-hunting has changed form and target in the global COVID-19 pandemic. Examples include (a) shunning foreign nationals studying in the country, subjecting them to violence, and sometimes rendering them homeless on the suspicion of carrying the contagion (Cerna et al., 2020), (b) violence against health workers (Manoj et al., 2021) and (c) exclusion of physicians and nurses from their homes based on unwarranted fear of COVID-19 infection (Rzymski \& Nowicki, 2020). The media houses and newspaper agencies have labeled acts as witch-hunting.

\footnotetext{
${ }^{1}$ Witch-Hunting is gender-based violence that mostly targets women, labeling them as 'witches.

2 Exposure to violence, objectification of their physical appearances, discrimination based on sex, and socioeconomic inequality.
} 
However, a smaller number of hero-welcoming ${ }^{3}$ based acts occur - governments instituting and enforcing laws against excluding healthcare workers from their homes, and stranded migrants nurtured with free food by the community. Elimination of acts of witch-hunting, and encouraging acts of hero-welcoming can effectively address the problem of discrimination and prejudice during the COVID-19 pandemic.

\section{Rationale}

The rationale for my research is that academicians and scholars have extensively studied prejudices during the pandemic. However, they failed to consider the other side of the pandemic, in which people have come together to extend help to one another. During the pandemic, deep-seated prejudices are manifesting themselves in new forms of violence and exclusion. Prejudices like social, economic, psychological, and physical are widespread in society. The rules of belonging and the familiar have guided society's evolution. Historically, social distance based on social boundaries has fueled and sustained prejudice. When infectious diseases or viruses are present, this social distance increases, and its further exacerbate the existing prejudices among the society and community people (Kim et al., 2021). The prejudice is also strengthened by economic, political, legal, and religious underpinnings, which add personal motive to it (Borah \& Das, 2019). Spreading rumors about suspected carriers of infection can increase discrimination, and its impact is beginning to be felt in India's private sector industries. Though more workers may return to work as pay is now based on attendance, workplace discrimination can have a negative impact on productivity. The vast unknown of COVID-19 has also strengthened personal and institutional prejudices. While laws prohibiting prejudice and bias exist in all countries, the contagion has resulted in a flood of statements on social media that contradict them (Pater, 2021). Furthermore, in the face of political motivation, prejudices gain strength and shape. Unfamiliar physical characteristics, combined with fear of COVID-19, create prejudices that endanger segments of the population (Eder et al., 2021).

However, the COVID-19 pandemic is also an opportunity for transformation. During COVID-19, the strength of community acts weakens prejudice. Several smaller crises may emerge during the larger COVID-19 crisis (Meester \& Ooijens, 2020). Sustenance acts, such as a doctor volunteering to drive a pregnant woman to a hospital, and essential services provided by government personnel in containment zones, are not uncommon. During a lockdown, both the government and the community stand out in the pandemic by providing stranded people with food and shelter. Another significant example of inclusion in the voluntary offer of people who have recovered from COVID-19 to participate in research for a cure (Tandon, 2020). While being dominated by prejudice, acts of sustenance, inclusion, and nurturing glimmer infrequently. Individuals, families, groups, and communities are all affected by prejudice. Healthcare, education, religion, law and order, politics, and transportation all bear the brunt of the damage (Sen \& Östlin, 2008). To effectively address the issue, acts of prejudice must be eliminated while acts of hero-welcoming are encouraged.

${ }^{3}$ People who have performed beyond the call of duty are welcomed as heroes by the family, community, locality, etc. 


\section{Objectives}

1. To systematically review the manifestations of 'witch-hunting' during COVID-19.

2. To systematically review the prevalence of 'hero-welcoming' during COVID-19.

3. To study the various factors for the inclusion and exclusion of such acts.

\section{Methods}

The latest articles on prejudices and discrimination during COVID-19 pandemics dates till 2021. A thorough Scopus and Google Scholar search was conducted using the search string: "Witch-Hunting" "COVID-19" [Tittle/Abstract/Keywords] OR "Hero-Welcome" "COVID-19" [Tittle/Abstract/Keywords]. This is called a Boolean Search. A total of 24000 articles were available. A total of 1200 articles were relevant of the study, where 700 research articles were available in witch-hunting context and 500 research articles were available in hero-welcoming context. The ontology (figure 1) of 'witch-hunting' and 'hero-welcoming' was formed after reviewing the 1200research papers.

The dimensions, elements, and boundaries of the witch-hunting and hero-welcoming ontology are defined in the paper by (Neogi et al., 2020). It hierarchically deconstructs the complexity of the policy problem i.e., discrimination and prejudice during COVID-19 and visualizes it in structured natural English and encapsulates its combinatorial logic. It organizes the policy problem, terminologies, taxonomies, and narratives systemically, systematically, and symmetrically (Cameron et al., 2017; Chandrasekaran et al., 1999; Cimino, 2006; Gruber, 1995, 2008). Ontology of Witch-Hunting and Hero-Welcoming During COVID-19 is a system's cognitive map for (a) designing policy alternatives, (b) determining effective, ineffective, and innovative policies, and (c) directing the choice through feedback and learning. It is a qualitative policy problem theory (Neogi, 2020). The dimensions of the ontology were developed based on a thorough review of the literature and is explained below.

In the ontology the Act dimension denotes witch-hunting and hero-welcoming acts. The Factor dimension denotes the possible factors - caste, ethnicity, gender, occupation, race, region, religion, and ideology. The Targets of such acts can be individuals, families, groups, and communities. The Type of acts can be economical, physical, psychological, and social. The acts of witch-hunting and hero-welcoming have potentially $256(8 * 4 * 2 * 4)$ pathways by combining the four columns of Factor, Type, Act and Target. Examples include the following: (a) occupation-based economic act herowelcoming act by community, (b) region based social act witch-hunting act by group, (c) ethnicity based physical act witch-hunting act by families. The impact (left-most dimension) of the acts could be economic, moral, physical, psychological, social, and political. Together with 256 acts of witchhunting and hero-welcoming, the ontology encapsulates $1,536(6 * 256)$ pathways. 


\begin{tabular}{|c|c|c|c|c|c|c|c|c|c|}
\hline Impact & & Factor & & Type & & Act & & Target & \\
\hline Economic & 冠 & Caste & $\bar{g}$ & Economic & 冠 & Witch-hunting & $\bar{a}$ & Individual & รี \\
\hline Moral & $\underset{\pi}{\stackrel{U}{\pi}}$ & Ethnicity & 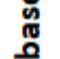 & Physical & $\underset{\pi}{\stackrel{u}{\pi}}$ & Hero-welcoming & $\vec{t}_{0}$ & Family & $\frac{1}{\frac{1}{3}}$ \\
\hline Physical & $\frac{0}{\varepsilon}$ & Gender & $\stackrel{0}{\stackrel{2}{2}}$ & Psychological & & & & Group & రु \\
\hline Psychological & $\underline{\underline{s}}$ & Occupation & & Social & & & & Community & $\infty$ \\
\hline Social & & Race & & & & & & & $\frac{2}{\frac{2}{3}}$ \\
\hline Political & & Region & & & & & & & 르 \\
\hline & & Religion & & & & & & & \\
\hline & & Ideology & & & & & & & \\
\hline
\end{tabular}

Figure 1. Ontology of Witch-Hunting and Hero-Welcoming During COVID-19

Source: Adapted from the 'Ontology of Prejudice and Projudice During COVID-19' (Neogi et al., 2020)

\section{Illustrative Pathways}

The impact of/by targets can be understood by acts embedded in these pathways. For example: -

(a) Occupation-based social act of hero-welcoming act by community.

Example; governments have instituted and enforced laws against excluding healthcare workers from their homes (Mishra, 2020).

(b) Region based social act of witch-hunting act by groups.

Example; people from northeast India was subjected to discriminated because of their physical appearances (Singha, 2021).

(c) Religion based physical act of witch-hunting by community.

Example; Tablighi Jamaat were subjected to hate and prejudices for spreading contagion (Raha, 2020).

(d) Occupation-based physical act of hero-welcoming act by community.

Example; various resident welfare associations came forward to help the stranded migrants' groups by offering them food and shelter (Rizvi, 2020).

\section{Analysis of the Ontology}

Societies across the world are in the grip of the COVID-19 pandemic. Indian society is multi-cultural and has varied ethnic practices and mores. Information about COVID-19 and access to health facilities may not be evenly distributed and understood. This strengthens old prejudices and gives rise to new ones. The social aspect of policy can extend into the pockets of prejudice and misinformation and dissolve them with evidence that will come from this study.

Continuing with the example of India where COVID-19 spread is amplified by the dense population, the ontology will provide a conceptual map of prejudicial and discriminatory acts, as well as the benevolent prejudicial ${ }^{4}$ act that are occurring in society. The Ontology of Witch-Hunting and HeroWelcoming During COVID-19 (Figure 1) has been used to anchor the discussion of the study. The acts of witch-hunting may be violence, exclusion, and the acts of hero-welcoming may be sustenance, inclusion, and nurturance. They are listed under Act in the ontology. These acts may be economic, physical, psychological, and social - listed under Type. Thus, physical violence would be a witch-

${ }^{4}$ Benevolent prejudice is a superficially positive prejudice that is expressed in terms of positive beliefs and emotional responses 
hunting act and psychological nurturance would be a hero-welcoming act. These types of acts may be targeted based on caste, ethnicity, gender, occupation, race, region, religion, or ideology - listed under Factor. Thus, ethnicity-based physical violence would be a witch-hunting act and region-based economic nurturance would be a hero-welcoming act.

The acts may be targeted by people. People as individuals, families, groups, and communities may be the source or the targets of the acts. Thus, ethnicity-based physical violence by a group would be a witch-hunting act, and region-based economic nurturance by a community would a hero-welcoming act.

The acts may have economic, moral, physical, psychological, social, and political impact on the acted entities. These are listed in the Impact column of the ontology. Thus, an ethnicity-based physical violence by a group would be a witch-hunting act that could have adverse economic, physical, psychological, and social impact on the institution and its members. Similarly, region-based economic nurturance by community would be a hero-welcoming act that could have positive economic and social impact on the group (Neogi et al., 2020).

Governments have enacted and enforced laws prohibiting the exclusion of healthcare workers from their homes, and stranded migrants have been nurtured by the community with free food (Sharma, 2020). During a lockdown, both the government and the community stand out in the pandemic by providing stranded people with food and shelter (Mehra, 2020). The media has extensively covered communities celebrating the services of people who are generally viewed with prejudice (Ahmad \& Murad, 2020). Another significant example of inclusion in the voluntary offer of people who have recovered from COVID-19 to participate in research for a cure (National Institute of Allergy and Infectious Diseases, 2021).

\section{Discussion}

The above ontology provided us a lens to look at the problem systematically and symmetrically. It helps us to understand the acts of witch-hunting which lead to prejudices and discrimination. It also helped us to understand the hero-welcoming acts which lead to positive prejudices.

\section{Discrimination of COVID-19 Positive Patients}

Since the pandemic outbreak in India, there has been a negative attitude toward those infected with the disease. COVID-19 patients were stereotyped as active coronavirus spreaders and treated as passive disease acquirers (Bhanot et al., 2021). As a result of such a stereotype, society resorted to a variety of negative treatments (ranging from social media posts against them to preventing their entry into residential areas and spreading rumors about them based on their religion, class, and caste) directed against them. Because this is an unusual condition, the devaluation associated with the COVID-19 mark is permanent (Balakrishnan \& Mukherjee, 2021). That is most likely why the consequences of its stigmatization are so severe that even those who have previously been diagnosed are still stigmatized, and even after defeating the virus, they have not been able to free themselves from social stigma (Link et al., 1997). People's fear is so intense that they have turned to scapegoats, particularly the poor, laborers, daily wagers, and migrants. According to reports, people working in Delhi (India) and residing in Haryana (India) were labeled as "corona carriers" by the Haryana Home Minister, devaluing the former for the possible spread of the contagion (HT Correspondent, 2020). 


\section{Discrimination Based on Occupation}

During this COVID-19 crisis, every country is attempting, to the best of its abilities and resources, to contain the pandemic's spread. Individuals, families, groups, and communities are banding together and demonstrating the pinnacle of prosocial behavior by assisting those in need. Doctors, nurses, and other health care workers, as well as police officers and municipal workers, are among those putting their lives in danger to serve their country. This is not unique to India (Bhanot et al., 2021). However, the doctors who work tirelessly to save patients' lives, as well as the police officers who work day and night away from their families, are mistreated by society. They are afraid and frustrated as a result of their difficult struggle, and they are also subjected to social stigma. People at the forefront of the pandemic response (also known as coronavirus warriors or frontline workers) are being shunned by their neighbors, landlords, and even family members (Dhawan, 2020). Because their fearful landlords have shunned, attacked, and accused the nurses and doctors, they have become homeless. They are shocked, humiliated, and hurt as a result of this (Bhalero, 2021). Such stigmatized treatment of doctors and other health care workers, police officers, and municipal workers is a classic example of occupation-based prejudice.

Migrant workers were another group of people who faced prejudices based on their occupation. The unorganized/informal sector was severely impacted when the nationwide lockdown was abruptly declared as a quick response measure to combat the pandemic. Within a week of the lockdown, India witnessed and continued to witness one of the world's most serious humanitarian crises: the mass migration of millions of workers driven by socioeconomic hardships (Biswas, 2020). The poor migrant workers had no choice but to return to their hometowns. Due to the closure of the public transportation system, they were forced to use alternative modes of transportation, such as bicycles and even foot, to cover distances of thousands of miles (Iyer, 2020). When the government made arrangements to bring back Indian students, tourists, and others who had become stranded in foreign countries, it paid little attention to the plight of these workers. Other incidents occurred when migrant workers were sprayed with disinfectant on two separate occasions by health/civic departments. The act was not only unreasonable but also highly indecent, emphasizing stigmatization as a function of people's social status (Staff Reporter, 2020).

\section{Discrimination Based on Region}

Residents of Northeast India have long been the targets of racism from Indian mainlanders due to their typical mongoloid features, which are similar to those of Chinese people. Northeast Indians have borne the brunt of racism and discrimination, and they are frequently treated as foreigners in their own country. During the COVID-19 pandemic, racism against Northeast Indians increased, and many cases were reported in which Northeasterners were called "corona," spat at, socially avoided, asked to vacate their homes by their landlords, beaten, suspended from work, or had difficulty accessing health care. However, the experience of stigma by Northeastern Indians in India has primarily been due to their facial similarities with Chinese people, who are also stigmatized by many as the cause of the pandemic's origin (Colney, 2020). 


\section{Discrimination Based on Religion}

During the month of March 2020, a religious meeting (congregation) was held at the Nizamuddin Markaz (Center) in Delhi for members of Tablighi Jamaat, an Islamic missionary, and reformist organization, from all over the world. It was later discovered that the majority of these members were coronavirus-positive, and before they could be tested and contained, they returned to their respective locations across India. The general public's fear of the virus's spread was at an all-time high at the time, and the entire Muslim community was stigmatized as virus spreaders (Ghosal et al., 2021). The stigmatization of the entire Muslim community has dominated the Indian public's reaction to COVID19. Some political leaders were heard referring to the Jamaat event as "corona terrorism," and congregation attendees as "enemies of humanity." Such reactions fueled feelings of hatred and placed undue blame for the virus's spread in this community. There has been a long history of religious prejudice and discrimination between Hindus and Muslims, indicating a lack of intergroup tolerance (Bhattacharya, 2020). The media's role in exaggerating society's negative reactions to the Muslim community could also be blamed. Sensationalized and inaccurate reporting, such as showing doctored videos of Jamaat members spitting on others, has contributed to public outrage and widespread mistrust of the Muslim community. As a result, there has been an increase in hostility, segregation, and violence directed at the entire Muslim community, as well as Twitter hashtags containing the phrase "corona jihad." These acts have served to validate Muslims' well-deserved subversion position and have contributed to the entrenchment of the already existing gaps between religious groups in society (Raha, 2020).

\section{'Hero-Welcoming' During COVID-19 Pandemic}

During the pandemic, many people banded together to assist those in need. People in the apartment complex, for example, were grouped to assist people who were isolated. People began their helpline services, providing medicine, groceries, and counseling to those in need. Workers from various trusts and organizations have also worked tirelessly for elderly care and dementia patients. Also, people took it upon themselves to intervene and began to call out these biased behaviors, especially in cases like domestic violence

\section{Occupation Based Acts of Hero-Welcoming}

The pandemic has also brought people closer together. People have begun to recognize the value of frontline workers. People all over India are flinging open their doors and windows to applaud and clap for healthcare workers. Hundreds of Indians have come out of their homes to applaud hospital workers as they change shifts in the evening (Ford, 2020). Another act of hero-welcoming is that the government took a brave step by enacting The Epidemic Diseases (Amendment) Ordinance, 2020, to put a stop to the acts of violence - including social ostracization - perpetrated on doctors and nurses by insensitive landlords and neighbors. The ordinance broadens the definition of "violent acts" and, as a result, provides better protection. While social stigma has been addressed in part, the government's macro-level actions, particularly in the procurement of PPE for frontline workers, leave much to be desired (Srivastava, 2020). During the pandemic, the ruling regime and the general public equated the healthcare worker with a "hero syndrome." COVID Warrior is a term that has been abundantly used. Of course, it is important to recognize the bravery of the healthcare community, which has attempted to serve the nation despite adversity (Higgins, 2020). 


\section{Nurturing the Migrant Workers}

The state's inability to control the spread of COVID-19 has resulted in a massive humanitarian crisis, which it has struggled to manage. As stranded workers and vulnerable families ran out of food, money, and patience, citizen-led initiatives stepped up to assist the stranded migrants (Gupta et al., 2020). Volunteers and members of civil society organizations have spent hours listening to people in need, preparing meals for over 100 people, and pleading with government officials to send relief when they have failed. The Centre submitted in an April report to the Supreme Court that NGOs across the country served 30.11 lakh meals during the first phase of the lockdown (Yadav \& Priya, 2021). Hospitality companies used their massive kitchens and manpower to provide meals and relief packages as well (Peter et al., 2020).

\section{Social Media Acting as a Boon}

News outlets, organizations, and the general public have used social media to disseminate both accurate and false information about the pandemic. The Centers for Disease Control and Prevention (CDC), World Health Organization (WHO), medical journals, and healthcare organizations have been updating and disseminating information across multiple platforms. Doctors are also joining social media groups to spread information about how to treat the disease (Schein et al., 2021). Physician Moms Group, which was founded five years before the pandemic, had so many people wanting to join the 70,000-strong group that Facebook's click-to-join code broke, and 10,000 more doctors waited for it to be fixed. The groups have enabled medical professionals to collaborate, share information, and help direct supplies to hospitals in need. All medical professionals have used social media to educate the general public about the importance of wearing a mask or the use of PPE's (Smith, 2020).

Even the Indian government was using social media to reach out to the country's large population. Information disseminated through social media has become increasingly important in combating infodemics ${ }^{5}$ and promoting accurate and reliable information for the public (Cinelli et al., 2020).

During the brutal second wave and a lack of critical lifesaving supplies, COVID-19 patients and their families in India turned to social media to save lives. As India set a new global record with multiple daily case counts of over 400,000 , its underfunded health system has struggled to keep up with the growing number of people in desperate need of assistance. Indian citizens and even hospitals themselves have taken to Twitter to plead for supplies, as they search for hospitals with open beds, flowing oxygen, and antiviral drug (Choudhury, 2021). Thousands of people have volunteered across the country to call hospitals and treatment centers regularly, catalog available resources, and post the information online for anyone in need. Volunteers are launching dedicated websites to fill gaps in the healthcare system and reduce losses caused by the disastrous rise in infections (Burgess, 2021).

\section{Religion based act of Inclusion}

More than 1000 positive cases were linked to the Tablighi Jamaat event at the start of the pandemic. The incident sparked widespread outrage and sparked reports of Islamophobia across the country. After thousands of attendees of the Tablighi Jamaat event in Delhi's Nizamuddin tested positive for

${ }^{5}$ An infodemic is too much information including false or misleading information in digital and physical environments during a disease outbreak. It causes confusion and risk-taking behaviors that can harm health. 
COVID-19, the event's chief, who was charged with culpable homicide, appealed to COVID-19 survivors in the Muslim community to donate blood plasma (Khan, 2020). This action comes after members of the Muslim community were singled out for blame for the pandemic's spread and were boycotted, subjected to violent attacks, and labeled as carriers of the coronavirus in the country. A total of 350 Tablighi Jamaat members who have recovered from coronavirus infection have pledged to donate plasma to help critical COVID-19 patients in Delhi hospitals (Nath, 2021).

\section{Mitigating Prejudices and Discrimination}

\section{- Word Sensitization}

Historically, it has been observed that the terms associated with a disease can potentially shape the lens through which society perceives that disease. Coining terms to address those affected by COVID19, or any illness for that matter, widens rather than bridges the gap between self and others. It is therefore critical to consider the words used with COVID-19 by not only medical professionals, but also organizations such as WHO and UNICEF, public directives and notices, promotional campaigns and advertisements, and the media. For instance, 'a COVID positive person' does not sound appealing. Instead, one can address it as 'a person suffering from COVID-19'. When used casually, terms like "coronized" can be perceived as labeling. Recognizing the affected as victims of the pandemic, rather than as the source, is beneficial.

\section{- Amplifying of Voices}

It is critical to involve and amplify the voices of those most affected by COVID-19 to develop stigmareduction strategies. It would include those who have recovered, those who are receiving treatment, their families, families of those who have died as a result of the disease, and frontline workers. Their experiences with COVID-19 and other intersecting stigmas can help to contextualize public health strategies for stigma reduction. Furthermore, recovery stories are likely to instill hope in the public, which may encourage people to talk about their symptoms rather than hiding them. As previously stated, social stigma is a deterrent to testing for the disease. As a result, learning from survivors that recovery is possible would encourage people to confront this stigma. Furthermore, the daily struggles of frontline workers should be highlighted. When their stories go unheard, they may not receive the recognition they deserve from society. The life risk that they take to provide us with a safe and healthy society remains in the background, while we exhibit stigmatized behavior toward them.

\section{- Be Responsible}

In a critical situation like this, it is not only on the government and frontline workers to act responsibly. Aside from them, political leaders, the media, and, most importantly, citizens must act responsibly and sincerely in combating the pandemic and related stigma. It is essential to stay informed. Inadequate knowledge can exacerbate stigma. As a result, it is critical to disseminate information about COVID-19 (e.g., what causes it, how it is transmitted, treatment, and prevention). While social media can be a useful platform for reaching the greatest number of people while lockdown is in effect, it must be used responsibly. Misuse of social media in the past has increased stigma rather than reduced it. At the same time, journalistic reports that focus on an individual's behavior or role in "spreading the virus" may cause public stigma. Such publication must be handled 
with care, bearing in mind the disruption it may cause in the lives of those who are involuntarily subjected to societal scrutiny.

\section{Limitations}

Although the ontological framework provides us with a lens to view the problem of prejudice and discrimination during COVID-19 systematically and symmetrically. The framework falls short that the articles were not methodically encoded onto the ontology. It is solely based on the author's review. Multiple coders using consensus coding can improve the results' reliability. The literature is still emergent. To determine whether the dynamics have changed or remained constant, the new literature must be examined. The literature is global in scope. There may be significant variations at the local, state, and national levels.

\section{Conclusion}

Pandemics or epidemics make no distinctions based on sociopolitical, ethnic, or economic lines. To deal with this pandemic, society needs its solidarity and cohesiveness more than ever. We may be able to develop immediate and long-term strategies to build empathy and social justice in the days ahead if we reduce the stigma surrounding this pandemic, its prevention, and containment. COVID-19 is just another opportunity to strengthen our social resilience. People have been thrown from a flourishing paradigm to a surviving paradigm as a result of the pandemic. The survival factor brings out both the good and the bad in people. The good in people are the intelligence factors that are guided by a value system that prioritizes humanity over sectarianism. And prejudice arises from a state of mind in which one is only concerned with one's own survival. Prejudice arose from a state of vulnerability. People have come to terms with their vulnerability. That is when the community came together to assist. As a result, we must recognize and continue positive acts.

\section{Acknowledgement}

I would like to express my gratitude to Dr. Arakalgud Ramaprasad, director of Ramaiah Public Policy Center for helping me in framing the ontology.

\section{References}

Ahmad, A. R., \& Murad, H. R. (2020). The Impact of Social Media on Panic During the COVID-19 Pandemic in Iraqi Kurdistan: Online Questionnaire Study. Journal of Medical Internet Research, 22(5), e19556. https://doi.org/10.2196/19556

Balakrishnan, V., \& Mukherjee, H. (2021). Stop the stigma: Virus is the enemy, not the person suffering from it. The Times of India. https://timesofindia.indiatimes.com/life-style/health-fitness/destress/stop-the-stigma-virus-is-the-enemy-not-the-person-suffering-from-it/articleshow/75068110.cms

Bhalero, Y. P. (2021). Discrimination Against Doctors: Why Has COVID-19 Turned Us Hostile? [She The People]. https://www.shethepeople.tv/home-top-video/discrimination-against-doctors-whyhas-covid-19-turned-us-hostile/

Bhanot, D., Singh, T., Verma, S. K., \& Sharad, S. (2021). Stigma and Discrimination During COVID19 Pandemic. Frontiers in Public Health, 8, 829. https://doi.org/10.3389/fpubh.2020.577018

Bhattacharya, D. P. (2020). Tabligh members undergoing treatment not cooperating: Doctors to Delhi govt. The Economic Times. https://economictimes.indiatimes.com/news/politics-and-nation/tabligh- 
members-undergoing-treatment-not-cooperating-doctors-to-delhigovt/articleshow/74969727.cms?from=mdr

Biswas, S. (2020). Coronavirus: India's pandemic lockdown turns into a human tragedy. BBC News. https://www.bbc.com/news/world-asia-india-52086274

Borah, L., \& Das, M. (2019). Witch-hunting in Assam: Myth or reality. Space and Culture, India, 7(3), 99-114. Scopus. https://doi.org/10.20896/SACI.V7I3.566

Burgess, S. (2021). COVID-19: How India is turning to social media to save lives during latest surge. Sky News. https://news.sky.com/story/covid-19-how-india-is-turning-to-social-media-to-save-livesduring-latest-surge-12284691

Cameron, J. D., Ramaprasad, A., \& Syn, T. (2017). An Ontology of and Roadmap for mHealth Research. International Journal of Medical Informatics, 100, 16-25. https://doi.org/10.1016/j.ijmedinf.2017.01.007

Cerna, L., Rutigliano, A., \& Mezzanotte, C. (2020). The impact of COVID-19 on student equity and inclusion: Supporting vulnerable students during school closures and school re-openings. https://www.oecd.org/coronavirus/policy-responses/the-impact-of-covid-19-on-student-equity-andinclusion-supporting-vulnerable-students-during-school-closures-and-school-re-openings-d593b5c8/

Chandrasekaran, B., Josephson, J. R., \& Benjamins, V. R. (1999). What Are Ontologies, and Why Do We Need Them? IEEE Intelligent Systems, 14(1), 20-26. https://doi.org/10.1109/5254.747902

Choudhury, S. R. (2021). Indians turn to social media for help as Covid crisis overwhelms the healthcare system. CNBC. https://www.cnbc.com/2021/05/25/india-covid-crisis-people-use-social-mediato-find-hospitals-medicine.html

Cimino, J. J. (2006). In defense of the Desiderata. Journal of Biomedical Informatics, 39(3), 299-306. https://doi.org/10.1016/j.jbi.2005.11.008

Cinelli, M., Quattrociocchi, W., Galeazzi, A., Valensise, C. M., Brugnoli, E., Schmidt, A. L., Zola, P., Zollo, F., \& Scala, A. (2020). The COVID-19 social media infodemic. Scientific Reports, 10, 16598. https://doi.org/10.1038/s41598-020-73510-5

Colney, K. (2020). Coronavirus increases racism against Indians from northeast. The Caravan. https://caravanmagazine.in/communities/coronavirus-increases-racism-against-indians-from-northeast

Dhawan, H. (2020). Why you need to clap for India's healthcare workers. The Times of India. https://timesofindia.indiatimes.com/home/sunday-times/why-you-need-to-clap-for-indias-healthcareworkers/articleshow/74752009.cms

Eder, S. J., Steyrl, D., Stefanczyk, M. M., Pieniak, M., Molina, J. M., Pešout, O., Binter, J., Smela, P., Scharnowski, F., \& Nicholson, A. A. (2021). Predicting fear and perceived health during the COVID19 pandemic using machine learning: A cross-national longitudinal study. PLOS ONE, 16(3), e0247997. https://doi.org/10.1371/journal.pone.0247997

Ford, S. (2020). Nation urged to applaud frontline healthcare staff tackling Covid-19. Nursing Times. https://www.nursingtimes.net/news/workforce/nation-urged-to-applaud-frontline-healthcare-stafftackling-covid-19-26-03-2020/

Ghosal, A., Schmall, E., \& Saaliq, S. (2021). Indian Muslims face stigma, blame for surge in infections. AP NEWS. https://apnews.com/article/religion-virus-outbreak-india-ap-top-news-newdelhi-ad2e96f4caa55b817c3d8656bdb2fcbd

Gruber, T. R. (1995). Toward Principles for the Design of Ontologies Used for Knowledge Sharing. International Journal Human-Computer Studies, 43(5-6), 907-928. https://doi.org/10.1006/ijhc.1995.1081

Gruber, T. R. (2008). Ontology. In L. Liu \& M. T. Özsu (Eds.), Encyclopedia of Database Systems. Springer-Verlag. 
Gupta, S., Nair, S., \& Varma, V. (2020). How citizens are helping migrants stranded by the coronavirus lockdown. The Indian Express. https://indianexpress.com/article/express-sundayeye/citizens-helping-migrants-stranded-coronavirus-lockdown-6412617/

Haldane, V., De Foo, C., Abdalla, S. M., Jung, A.-S., Tan, M., Wu, S., Chua, A., Verma, M., Shrestha, P., Singh, S., Perez, T., Tan, S. M., Bartos, M., Mabuchi, S., Bonk, M., McNab, C., Werner, G. K., Panjabi, R., Nordström, A., \& Legido-Quigley, H. (2021). Health systems resilience in managing the COVID-19 pandemic: Lessons from 28 countries. Nature Medicine, 27(6), 964-980. https://doi.org/10.1038/s41591-021-01381-y

Higgins, C. (2020). Why we shouldn't be calling our healthcare workers "heroes." The Guardian. https://www.theguardian.com/commentisfree/2020/may/27/healthcare-workers-heros-languageheroism

HT Correspondent. (2020). Haryana home minister identifies 'corona-carriers', seeks Delhi govt's help. Hindustan Times. https://www.hindustantimes.com/india-news/haryana-home-ministeridentifies-corona-carriers-seeks-delhi-govt-s-help/story-N5NFoxHzOlWpdbhvXrBprO.html

Iyer, S. (2020). Over 1 crore migrant labourers return to home states on foot during Mar-Jun: Govt. The Hindu. https://www.thehindu.com/news/national/over-1-crore-migrant-labourers-return-to-homestates-on-foot-during-mar-jun-govt/article32674884.ece

Khan, F. (2020, April 28). Tablighis donate plasma, urge others to be donors as they look to put Covid controversy behind. ThePrint. https://theprint.in/india/tablighis-donate-plasma-urge-others-to-bedonors-as-they-look-to-put-covid-controversy-behind/410033/

Kim, M.-C., Kweon, O. J., Lim, Y. K., Choi, S.-H., Chung, J.-W., \& Lee, M.-K. (2021). Impact of social distancing on the spread of common respiratory viruses during the coronavirus disease outbreak. PLOS ONE, 16(6), e0252963. https://doi.org/10.1371/journal.pone.0252963

Link, B. G., Struening, E. L., Rahav, M., Phelan, J. C., \& Nuttbrock, L. (1997). On stigma and its consequences: Evidence from a longitudinal study of men with dual diagnoses of mental illness and substance abuse. Journal of Health and Social Behavior, 38(2), 177-190.

Manoj, M. A., Padubidri, J. R., Saran, J., Rao, S. J., Shetty, B. S. K., \& D’Souza, H. (2021). Violence against healthcare personnel in India: Covid-19 prompts stricter laws. Medico-Legal Journal, 00258172211006276. https://doi.org/10.1177/00258172211006276

Meester, J., \& Ooijens, M. (2020). COVID-19 Impact on the Value Chain - Conceptual paper [CRU Policy Brief]. https://www.clingendael.org/sites/default/files/2020-06/Conceptual_paper_COVID19_Impact_on_the_Value_Chain_June_2020.pdf

Mehra, R. (2020). How to help the most vulnerable during the covid-19 lockdown. Mint. https://www.livemint.com/mint-lounge/features/how-to-help-the-most-vulnerable-during-the-covid19-lockdown-11585631303316.html

Mishra, H. (2020). Upto 7 years in jail for attacking Covid warriors, govt brings in ordinance. India Today. https://www.indiatoday.in/india/story/central-govt-ordinance-to-protect-medical-staffcovid19-coronavirus-1669784-2020-04-22

Nath, V. (2021). Recovered Tablighi Jamaat Members Donate Blood Plasma for COVID-19 Patients. The Wire. https://thewire.in/rights/tablighi-jamaat-donate-blood-plasma

National Institute of Allergy and Infectious Diseases. (2021). Volunteer for COVID-19 Clinical Trials | NIH: National Institute of Allergy and Infectious Diseases. https://www.niaid.nih.gov/clinicaltrials/covid-19-clinical-trials

Neogi, D. (2020). A Study on the Practice of Witch-Hunting in Assam, an Ontology. TIIKM, 5(1), 18. https://doi.org/10.17501/24246743.2020.5101

Neogi, D., Sanjeev, A., \& Ramaprasad, A. (2020). Report on the Ramaiah Webinar on Prejudice and Projudice During Covid-19. RPPC. https://doi.org/10.13140/RG.2.2.23471.56486 
Pater, S. N. (2021). Combating bias and stigma related to COVID-19. Https://Www.Apa.Org. https://www.apa.org/topics/covid-19/bias

Peter, B., Sanghvi, S., \& Narendran, V. (2020). Inclusion of Interstate Migrant Workers in Kerala and Lessons for India. The Indian Journal of Labour Economics, 63(4), 1065-1086. https://doi.org/10.1007/s41027-020-00292-9

Raha, S. (2020). Tablighi Jamaat Coronavirus Hotspots: Is Media Coverage Biased? TheQuint. https://www.thequint.com/voices/opinion/coronavirus-spread-tablighi-jamaat-tv-media-tiktok

Rizvi, S. (2020). Clapping to slapping - India did everything other than social distancing this week. ThePrint. https://theprint.in/opinion/newsmaker-of-the-week/india-did-everything-other-than-socialdistancing/389778/

Rzymski, P., \& Nowicki, M. (2020). COVID-19-related prejudice toward Asian medical students: A consequence of SARS-CoV-2 fears in Poland. Journal of Infection and Public Health, 13(6), 873876. https://doi.org/10.1016/j.jiph.2020.04.013

Schein, R., Wilson, K., \& Keelan, J. (2021). LITERATURE REVIEW ON EFFECTIVENESS OF THE USE OF SOCIAL MEDIA A REPORT FOR PEEL PUBLIC HEALTH (p. 63).

Sen, G., \& Östlin, P. (2008). Gender inequity in health: Why it exists and how we can change it. Global Public Health, 3(sup1), 1-12. https://doi.org/10.1080/17441690801900795

Sharma, N. C. (2020). President approves ordinance to protect healthcare workers. Mint. https://www.livemint.com/news/india/president-approves-ordinance-making-violence-againstdoctors-punishable-offence-11587616074735.html

Singha, A. (2021). Racism against Northeasterners: How Covid-19 pandemic propelled the existent social evil into an extreme. TheLeaflet. https://www.theleaflet.in/racism-against-northeasterners-howcovid-19-pandemic-propelled-the-existent-social-evil-into-an-extreme/

Smith, M. (2020). Doctors turn to social media to develop Covid-19 treatments in real time. ThePrint. https://theprint.in/world/doctors-turn-to-social-media-to-develop-covid-19-treatments-in-real$\underline{\text { time/387593/ }}$

Srivastava, G. (2020). Decoded: How the new epidemic Act aims to protect healthcare workers. Business Standard India. https://www.business-standard.com/article/current-affairs/decoded-how-thenew-epidemic-act-aims-to-protect-healthcare-workers-120100900065 1.html

Staff Reporter. (2020). Migrants in India sprayed with disinfectant to fight coronavirus. Al Jazeera. https://www.aljazeera.com/economy/2020/3/30/migrants-in-india-sprayed-with-disinfectant-to-fightcoronavirus

Tandon, S. (2020). Covid-19: Availability of essential goods falls in last two days. Mint. https://www.livemint.com/news/india/covid-19-availability-of-essential-goods-falls-in-last-two-days11586520749732.html

United Nation Human Rights. (2020). RACIAL DISCRIMINATION IN THE CONTEXT OF THE COVID-19 CRISIS. https://www.ohchr.org/Documents/Issues/Racism/COVID19_and_Racial_Discrimination.pdf

United Nations. (2020). Human rights are critical - for the response and the recover. UN. https://unsdg.un.org/sites/default/files/2020-04/COVID-19-and-Human-Rights.pdf

Yadav, S., \& Priya, K. R. (2021). Migrant Workers and COVID-19: Listening to the Unheard Voices of Invisible India. Journal of the Anthropological Survey of India, 70(1), 62-71. https://doi.org/10.1177/2277436X20968984 